\title{
The Trumpeter
}

Journal of Ecosophy

\section{Three Natural Philosophers}

\section{Molly K Sturdevant}

Volume 34, Number 1, 2018

Focus on Laudato Si'

URI: https://id.erudit.org/iderudit/1060955ar

DOI: https://doi.org/10.7202/1060955ar

See table of contents

Publisher(s)

Athabasca University Press

\section{ISSN}

1705-9429 (digital)

Explore this journal

Cite this document

Sturdevant, M. (2018). Three Natural Philosophers. The Trumpeter, 34(1),

157-159. https://doi.org/10.7202/1060955ar

This document is protected by copyright law. Use of the services of Érudit (including reproduction) is subject to its terms and conditions, which can be viewed online.

https://apropos.erudit.org/en/users/policy-on-use/ 


\section{Three Natural Philosophers}

MK Sturdevant

I.

Empedocles

In $460 \mathrm{BC}$, there was no toilet paper.

So you can imagine it took a bit of work, and the far corner of his cloak, to clean himself

after retreating behind a large stone for some privacy.

He was on his way to the temple, to the altar, but first to the artist's little plot of ground behind the building.

There, he said to her: Hey, Friend, you may have mixed red with blue in a novel way, but there was never a time in which neither red nor blue existed.

Tell me something I don't know.

The artist continued painting her votives, mixing elements like a god.

She worked quietly for some time, as he grew jealous

of her intimacy with the products of her labor.

The storm clouds began to gnash a seagull overhead, which reminded him:

Furthermore- he said, scratching himself-

we are bumpy and flawed in this life.

If there is a sphere, then there is a God, for It is perfect;

without sides, genitals, feet. 
She didn't even look up.

There was now an emptiness under him, in the air under his wrap, in the cruel tattering of grass on the mountainous terrain upon which no garbage had yet existed, an acreage which he wanted somehow to fill.

II.

Anaxagoras

There was this young tree, fissured and brown, mangy, new and lovely at the same time, which so perplexed a passerby that he could not help his excitement, and could not stop his tears of joy whenafter having cut it down with eight swift falls of his hatchethe felt palpably the interconnectedness of all things in the universe.

That night, his wife asked him if he might just take a lover of some sort for the evening so that she could retreat to her own chambers and decorate some useful objects.

He understood, of course, and asked for someone to be sent over. He kissed his wife on the forehead. He hung up his hatchet. In the wide room of the pater familias he lay alone, waiting upon his couch, and he felt the moon rise, always after a skein of wine, he felt the estate tipping slightly into the sky, maybe just a little downward towards Ionia. 
The lover was kind enough to just let him sleep in the whiteish darkness.

There was no point in guessing the subject of his nightmares;

always it was a death by being lost

in the scrubby, maddening woods out past the boundaries, unable to command his own limbs past hunger and cold, his Mind an enraged slaver facing total mutiny, alone on some crust of rock.

III.

Lucretius

These ways that the waves roll are better than all the fleeing traffic.

Unless today we make some mark upon the air and manifest our pattern, and how we are swept by what wind

Unless we say it, there on the promenade, loud on the sidewalk perched on the curve arcing its concrete neck beneath the bikes and scurries and screams of birds flapping hard through our signals

Only then will we say there is no gap in the universe.

By that I mean Lucretius - the poor devil- hoped you and I would observe the swerve more than the sameness and decide to close in on no distance. 